\title{
Multilateral Development Banks: Counter-cyclical Mandate and Financial Constraints
}

\author{
Andrea Molinari ${ }^{*}$ \\ Leticia Patrucchi ${ }^{* *}$
}

\begin{abstract}
Given their attractiveness as a source of financing for the least developed countries, multilateral development banks (MDBs) have grown in quantity and size supported by their sources of financing. We believe that this 'resource dependency' has not been sufficiently questioned in the literature, especially regarding the credit exposure these organizations have with their largest borrowing members. This article characterizes and identifies the differential effects of the three sources that make up the dependence on resources in the MDBs: capital contributions, leverage in the markets and their credit function. We analysed these sources particularly at the International Development Bank (IBRD), the Inter-American Development Bank (IDB) and the African Development Bank $(\mathrm{AfDB})$ and in two recent events: the risk exchange implemented by the referred MDBs in 2015 and the effect of the Argentina's selective default on the IDB's capital adequacy (2014). We find an increasing relevance of leverage and the size of loans, which models a dependence on resources that weakens the development mandate of these organizations.
\end{abstract}

Keywords: multilateral development banks; resource dependence; conditionalities; market risk; development mandate.

\section{Introduction}

Multilateral and regional development banks (MDBs and RDBs, respectively) have been an attractive source of financing for developing countries, multiplying both in quantity and size since the Bretton Woods agreements. Within such a framework, these banks were designed with the aim of establishing global economic rules for development. Their

\footnotetext{
Instituto Interdisciplinario de Economía Política (IIEP-BAIRES), Ciudad Autónoma de Buenos Aires, Argentina; anmolinari@gmail.com. ORCID iD 0000-0002-9951-2633.

** Universidad Nacional de Moreno (UNM), Moreno, Argentina; lepatruc@gmail.com. ORCID iD 00000002-6216-1868.
} 
advantage lies in a cooperative-based organisational model offering access to 'soft' financing (i.e. under more beneficial conditions). However, that model has not been static or uniform.

We assume that the shape and dynamics of these banks sustain a particular balance between two dimensions: 'representative legitimacy' and 'resource dependence' (Strand and Trevathan 2016). The former refers to the type of government arrangement that is accepted by member countries and the distribution of political power within each MDB. The latter relates to the capital needs to meet the objectives of each bank, that is, its material support. Our work focuses on this second dimension, exploring how it shapes MDBs. In doing so, and without ignoring the interdependence between both dimensions, we observe the need to concentrate on resource dependence, considering a growing field of analysis that seeks to broaden the scope of inquiry beyond the focus on shareholder contribution (e.g. Birdsall 2006; Babb 2009; Humphrey 2015a, 2015b, 2017b; Park and Strand 2016).

More specifically, the literature identifies three sources of MDB funding: (i) capital contributions from members, (ii) international capital market issuance, and (iii) borrowing dynamics. Each of these sources imply different dependencies (in terms of who conditions access to the resources needed by the MDB and how such access is conditioned) and a particular relevance in each bank's mix of resources. The literature (Babb 2009; Humphrey 2015a; Park and Strand 2016, among others) has paid differentiated attention to each of these sources. The first one, which focuses primarily on capital negotiations, and on what countries have a greater voice, has been the most studied. Financial markets (source ii) - or other non-State stakeholders - have also grown as relevant players in the resource dynamics of these organisations (Humphrey 2015a, 2015b, 2017b; Graham 2017; Helleiner and Wang 2018). We identify, however, gaps in the understanding of the scope and relationships of the third source, which we refer to here as borrowing dynamics.

We observe that the dynamics with borrowing countries have gained prominence as a resource dependence factor within the financing model of MDBs, together with the interdependence among the three aforementioned sources. Such borrowing dynamics encompass reflows (e.g. as stated by Babb 2009), but they also (and mainly) involve a bank's relationship with its middle-income borrowers.

This article begins by briefly describing the 'Bretton Woods model', to subsequently conceptualise the sources of MDB funding and their interrelations, with emphasis on the one we consider to be the most neglected in the literature: the borrowing dynamics. In that section, we analyse how these sources are presented in three MDBs: a multilateral one - the International Bank for Reconstruction and Development (IBRD) - and two regional ones - the Inter-American Development Bank (IDB) and the African Development Bank (AfDB). We use secondary information (i.e. financial statements, presentations for investors and policy guidelines from these banks, together with credit rating agencies reports). We have chosen these organisations because they offer two cases (analysed in the section 'Expanding the scope of borrowing dynamics') showing the importance of borrowers in MDB's resource dependence, namely the risk swap agreed on by these three banks (in 2015) and the dynamics between Argentina and the IDB within the context 
of the country's 2014-2015 selective default (SD) rating. Finally, our conclusions outline the main future challenges based on the analysis of the conditionalities entailed by these sources and their relationship with the institutional dynamics of these organisations.

\section{The Bretton Woods model}

The Bretton Woods institutions, which include the International Monetary Fund (IMF) and the IBRD, were created in a post-war context for the purposes of establishing global economic rules. Their origin goes back to an era dominated by criticism levelled against self-regulating market views and the endorsement of ideas rooted in economic planning principles. The main objectives of Bretton Woods were twofold. In addition to seeking to generate a new global institutional trade and finance framework, laying the foundations of prosperity and stability of the international economic order, it addressed cooperation aspects. Precisely, as Nemiña and Larralde (2018) state, beyond the leadership of the USA and Great Britain in negotiations, the influence of Bretton Woods on development also was a response to the participation of peripheral countries. In this sense, MDBs originally emerged as institutions in search of strengthening the voice and participation of sovereign states to promote international financial stability and cooperation as global public goods (Hirschman 1970).

The agreements reached, regardless of the differences between the British and American views - led (respectively) by J. M. Keynes and H. D. White - marked, at the time, a strong progressive character in the original design of these institutions (George 2004). This is documented by Rapoport and Médici (2007) in their article suggestively entitled 'Corazones de izquierda, bolsillos de derecha...' ('Leftist Hearts, right-wing pockets...'), highlighting the need to regulate markets, and fostering cooperation, balanced growth and global development.

Founded in 1945, these MDBs 'were established in order to foster development by acting as mediators in capital transfers from surplus countries to those facing scarcity' (Vivares 2013: 13). Subsequently, they inspired regional banks, such as the IDB and AfDB. ${ }^{2}$

However, the effectiveness of these institutions is currently being limited by their scarce resources to respond to the developing world's needs and their difficulties to impose greater conditionalities on borrowing countries (Woods 2008). In addition, the literature also highlights certain 'miscalculations' in that 'the construction of a more development-friendly international economic order was a much slower and uneven process after the war than the Bretton Woods architects had anticipated' (Helleiner 2015: 16).

The counter-cyclical function of these banks implicated in the predominance and coordinated action of national sovereign actors. This was expressed in a governance structure dominated by sovereign owners (Board of Governors and Executive Board of Directors) and a capital that is mainly callable (i.e. with a low proportion of cash). Hence, from the beginning, this model cultivated a mixed resource dependence (Humphrey 2015b). 


\section{How are MDBs funded?}

Babb (2009) identifies three sources of MDB operating resources: contributions from their members, bonds issued in international capital markets, and the borrower's role in the form of loan 'reflows' (i.e. payment of interests and charges). Thus, just like private banks, MDBs base their funding on the contributions from their shareholders (adding external resources), except that the former seek economic benefits from their financial intermediation function. ${ }^{3}$ That is, for private banking, loan reflows are key, and acquire a clear lucrative nature vis-à-vis the soft loan conditions of MDBs (low interest rates and long repayment terms). This is not the case with development (multilateral, regional or sub-regional) banks, where a cooperative statutory principle prevails.

Babb (2009) also states that, unlike private banks, the return on investment of MDBs is more difficult to quantify, since their owners (and especially non-borrowing countries) generally use them for various purposes. These range from the most acclaimed ones (i.e. poverty alleviation) to the least publicised, but also central, ones (e.g. procurement contracts and interference in borrowers' policy agendas). The conception of what kind of shareholder value prevails often depends on the internal political dynamics in donor (non-borrowing) countries. That is, unlike private banks, the performance of MDBs 'corresponds to a shifting list of goals that are prioritized through domestic political processes' (Babb 2009: 45). In non-borrowing countries, such goals are often diluted behind the argument of governments being held accountable by their taxpayers. This led the most developed nations (e.g. the USA) throughout the history of MDBs to allow for the expansion of the World Bank Group and to provide resources to establish (among others) the IDB. In turn, they demanded a design of government structures which would grant them a key decision-making power, for example, by exercising a veto power.

There are several examples of non-borrowing countries using MDBs to promote their national foreign policy interests. A paradigmatic one, considering our case of analysis, is the US proneness to block lending for Argentina. ${ }^{4}$ Other examples include some of the reactions to the 2012 nationalisation of the Argentinian previously state-owned oil company YPF, expropriated from the Spanish company Repsol. ${ }^{5}$ Newspapers of that time document several pressures from the USA, ${ }^{6}$ together with Spanish public obstructions at the IDB: in June 2012 'Spain began to hamper the granting of loans for Argentina at the Inter-American Development Bank [... and] succeeded in postponing twice the discussion of a loan by the IDB board.7

In a similar vein, Humphrey (2015a) argues that MDBs depend centrally on two sources: the member countries as contributors of capital (i.e. as both political and financial owners), and the buyers of their bonds (i.e. the essential liquidity providers for their operations). While the main shareholders play an important role, the author considers that it is necessary to better understand the limitations of these shareholders' power, given that the current nature of MDB funding is increasingly focused on financial markets.

For Park and Strand (2016), the concept of resource dependence is useful to analyse whether the behaviour of MDBs is driven either internally or externally. They use it to study the impact of changes in the balance of geo-economic power on the demand of 
middle-income borrowers, given the conditionalities associated with the loans of MDBs vis-à-vis a significant private sector option or alternative bilateral assistance for development. In turn, and given their dependence on solvent portfolios, MDBs may end up redirecting their credit practices to follow borrowers' interests.

According to the three sources mentioned (capital contributions, bond market issuance and borrowing dynamics), Figure 1 summarises the ways in which MDBs obtain resources and identifies the central stakeholder for each funding source.

Figure 1 - Funding sources of MDBs

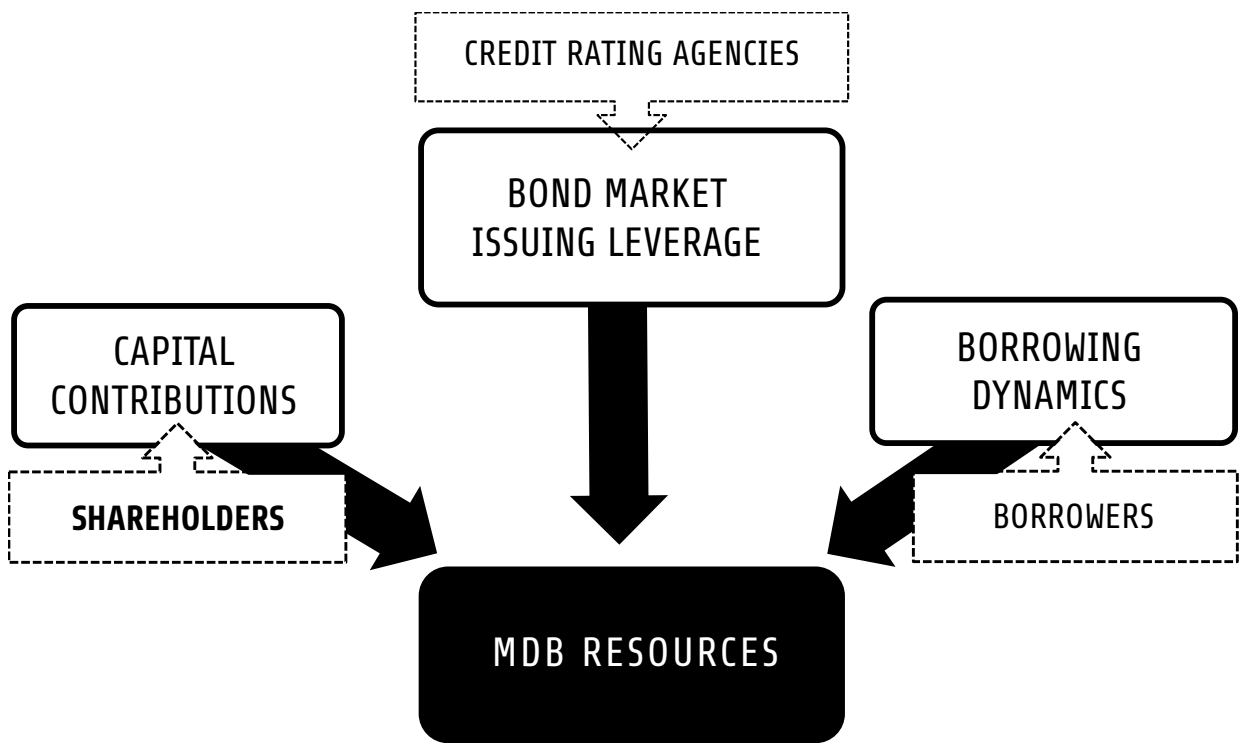

Source: Created by the authors.

In each bank, the form and relevance of each of these sources determine a specific power balance among the three players, influencing each source (shareholders, credit risk rating agencies, and borrowing countries). Consequently, the concept of resource dependence allows us to examine the changes in the policies of MDBs within a framework of international political economy. To illustrate our point, this section (see the subsection 'Characterisation of the three sources of resource dependence') delves into the conceptualisation of the three sources of resource dependence, and describes their characteristics in the IBRD, IDB and AfDB.

Before proceeding, we believe that it is worth highlighting the role of credit risk rating agencies (in the following subsection 'How do credit risk rating agencies look at MDBs?') for two reasons. First, these stakeholders are generally considered as 'key players in the global economy' (Weiss and Wilkinson 2013: 4). Second, and despite having defined them as the main stakeholder within the leverage dynamics (as their primary funding source), 
these agencies also condition both capital contributions and the borrowing dynamics (first and third sources), given their assessment of the risk considered by the market.

\section{How do credit risk rating agencies look at MDBs?}

It is worth noting that we focus here on the Standard and Poor's (S\&P) rating system, as it uses the most restrictive and quantitative methodology. The fact that the other two main agencies (Moody's and Fitch) value MDBs in a 'less prescriptive and more subjective' way, positions S\&P as an 'extreme case' (Humphrey 2017b: 9) highly consulted by the market.

In November 2012 - and as a result of pressures for more efficient and transparent risk rating exercises following the 2008 crisis - S\&P published a new methodology for assessing the credit risk of multilateral institutions (for details of their calculation and the origin of these changes, see Humphrey 2017b). The publication of S\&P's methodology made it possible to understand the different dimensions involved in the credit risk assessment of MDBs. However, it also showed several weak points in terms of applicability and consistency, reflecting a significant degree of (technical or political) discretion by the agency when assessing the risk of MDBs. ${ }^{8}$

We focus on three criticisms that have a strong impact on borrowing dynamics. In particular, the overvaluation of the portfolio concentration risk, the undervaluation of the preferred creditor treatment (PCT, granted to MDBs by borrowing countries), and the undervaluation of the callable capital committed by shareholders (Humphrey 2015b; Perraudin, Powell and Yang 2016; Humphrey 2017b).

First, to adjust the formula for portfolio concentration, S\&P incorporated new criteria to measure risk-adjusted assets, based on a calculation that the agency had initially developed to evaluate commercial banks. For that reason, such a formula represents a diversification potential typical of private banks (200/500 clients) (Gordy and Lütkebohmert 2007). The problem with this kind of measurement is that portfolio concentration is inherent in MDBs in general (and RDBs in particular). That is, unlike most private commercial banks, MDBs have relatively high exposures to a few borrowers. Hence, these banks end up withholding more capital (i.e. not lending) for reasons that are intrinsic to their logic of development banks. ${ }^{9}$ And this, in turn, restricts their counter-cyclical function or original development mandate.

On its part, the preferred creditor treatment means that borrowers will continue reimbursing MDBs even facing default (or delay) on payments to other creditors. Such PCT does not have a legal basis, but it is a practice that reflects both the reciprocal (mutual or cooperative) nature of MDBs and their borrowers' concern to remain in good standing with these banks in difficult (or crisis) times. ${ }^{10}$ In this sense, Humphrey (2015b) shows that PCT has resulted in a much more solid record of payments of MDBs vis-à-vis commercial banks.

Finally, S\&P's 2012 formula only contemplates the callable capital with (at least) a rating equal to or higher than that of the MDB in question. This is the reason why, for several years now, neither the callable capital of the IBRD or the IDB (both with AAA rating) has 
included, for example, the contribution from their main shareholder (the USA, which lost its AAA rating in 2011). Something similar, although of lesser magnitude, happens with France in the AfDB (also downgraded in 2011). ${ }^{11}$ This leaves MDBs with very low margins of capital subscribed by countries with AAA ratings. ${ }^{12}$ By way of example, to date, this covers only $14.4 \%$ of the IBRD's capital (voting powers as of August 2019), 6.9\% in the IDB (as of September 2019) and 13.7\% in the AfDB (as of January 2019).

Further, Perraudin, Powell and Yang (2016) find that the changes mentioned are extremely conservative to rate MDBs. Humphrey (2015b) considers that this methodology has a great impact, both on the credit risk rating of these banks and their ability to fulfil their development mission. Ultimately, following this methodological change, some organisations, such as the IDB, needed to re-assess their capital requirements in order to prevent their $\mathrm{AAA}^{13}$ rating from being compromised. In this sense, the methodological change mentioned has forced credit rating agencies to evaluate MDBs in a similar way to private banks.

\section{Characterisation of the three sources of resource dependence}

Resource dependence allows us to examine changes in the policies of MDBs within the framework of international political economy. To illustrate, this subsection elaborates on the conceptualisation of each of the three of resource dependence sources identified in Figure 1, and describes their characteristics in the IBRD, the IDB and the AfDB.

\section{Capital increases}

MDBs use capital increases to expand their activities. The most relevant and regular ones are general capital increases (GCI), through which shareholder governments agree to inject capital to support and/or expand lending. Each GCI arrangement is unique, and generally occurs after intense negotiations among the main shareholder countries. They involve periodic negotiation rounds which have been historically spaced out (from fiveyear rounds to every 8-10 years), but which have also been increasing in volume (e.g. the IDB's and AfDB's last GCIs - in 2010 - doubled their total capital).

There are two other types of capital contributions: ${ }^{14}$ replenishments ${ }^{15}$ (i.e. donations for concessional windows which become exhausted whenever they are used), and selective increases (generally used to realign shareholdings). Given their limited character, we do not analyse these last two mechanisms here.

Capital increases consist of the effective payment of only part of the total assumed commitment (referred to as 'paid-in' or 'in cash' capital), which, in the three organisations studied here, ranges between $5 \%$ and $10 \%$. The most substantial part of such increase is 'callable' (or guaranteed) capital, representing a financial commitment assumed by the shareholder countries of an MDB. Capitalisations of most MDBs have had a growing dominance of callable capital. ${ }^{16}$

This type of capital can be requested (or demanded) by an MDB in very special cases - e.g. problems concerning the access to either private capital markets or its own resources 
to meet its debt obligations. However, this is generally unlikely and has never occurred in the history of these organisations (Babb 2009; Park and Strand 2016; S\&P 2018a, 2018b, among others).

In particular, the IBRD had an initial capital subscription (in 1944) of US\$9.1b, with about $20 \%$ in cash, and, in the following subscriptions, this proportion varied between $6 \%$ and $12.5 \%$. Perhaps due to their regional status, the IDB and the AfDB are more extreme examples. The initial capital of the IDB (in 1959) was US $\$ 850 \mathrm{~m}$, with US\$400m payable in cash. In its last capitalisation (approved in 2010, with an increase of US\$70b), only US $\$ 1.7 \mathrm{~b}$ were paid in. The AfDB had an original capital (in 1964) of US\$250m with 50\% in cash, while in its last capital increase (approved in 2010), only 6\% (of a total amount of US\$65.3b) was in cash.

The preponderance of callable capital is key in the market leverage dynamics of these organisations. The relevance of such capital, when valued by rating agencies as 'strong enough' (AAA), and the trajectory of the PCT make MDBs financially sounder. In this sense, the mere threat of losing such credit rating causes 'anxious responses and almost all institutions received significant capital increases in the aftermath of the crisis' (Berglof 2015: 35).

In any case, the subscribed capital of MDBs depends largely on the contributions from non-borrowing countries for several reasons. First, their main contributor is a non-borrower: US shares account for between $30 \%$ and $15.6 \%$ (in the IDB and IBRD, respectively). This country's veto power enables (or blocks) the necessary negotiations for each GCI, thus conditioning its own possibility. Likewise, these countries are net contributors (i.e. they do not obtain capital from the cooperative), and, finally, their callable capital is of 'higher quality' given the higher credit risk ratings of developed countries.

Hence, the aforementioned conditions turn non-borrowing countries into those which normally impose ${ }^{17}$ their positions on the actions of these banks. And this is especially the case in the negotiations of capitalisations (Babb 2009; Lavelle 2011), giving these instances not only material, but also high political relevance. For example, in its Ninth General Capital Increase (GCI-9), the IDB made it explicit that the Bank should maintain a triple-A rating and, among other things, introduced macroeconomic safeguard conditionalities in the access to financing (e.g. the Macroeconomic Sustainability Analysis) (OVE 2018). These innovations triggered a strong resistance in borrowing countries. For example, Brazil, at the 2013 IDB Annual Assembly, expressed a 'concern that arises from any kind of macroeconomic analysis that becomes an instrument to limit the IDB support for economies facing short-term challenges' (Belchior 2013). ${ }^{18}$ And this resistance even led some members, such as Venezuela, to denounce them as violating the IDB's Constitutive Agreement.

\section{Leverage}

As mentioned, the capital of MDBs normally contains a large callable (or guaranteed) part. From this callable capital, banks borrow funds (i.e. issuing debt or bonds) from the international capital markets. This is their banking function and main 'advantage' with 
respect to private investment banks. Likewise, markets depend on signals from sovereign States regarding the security of buying MDB bonds, that is, with 'shareholder support.' In theory, with the callable capital of the richest countries in the world, MDBs would represent a solid investment, especially when none of these banks has ever resorted to such callable capital of shareholder governments. ${ }^{19}$ That is, the possibility of MDBs to leverage through their loans in international capital markets is significantly enhanced by their high credit capacity (Perraudin, Powell and Yang 2016).

Humphrey (2015a) analyses in detail how this source has become increasingly important over time. The IBRD came out very early to dominate the financial market (already in 1946), configuring what Humphrey refers to as 'Wall Street-friendly management' (Humphrey 2015a: 4). Seventy-five years later, the World Bank Group's concessional window (the International Development Association, IDA) reached another historic milestone as the first of its kind to go to the capital markets. Since this window was financed almost exclusively via refills (granting donations), the issuance of bonds was a sign of erosion of the cooperative pillars of the Bretton Woods model. In Jim Yong Kim's own words, the then President of the Group: 'IDA's entry to the global capital markets is historic - the latest transformational shift in how we approach development finance - [...] inherits IBRD's reputation as an innovative issuer in connecting markets with development impact' (World Bank, President Speech, 19 April 2018). The relevance of such financial intermediation is also expressed in the Bank's own definition of its strict loan policy, maintaining, for example, a maximum debt (1:1) ratio (loans over subscribed capital, reserves and surpluses). ${ }^{20}$ The IDB and AfDB also get most of their resources by leveraging in private financial markets.

The dependence of MDBs on leverage positioned international credit agencies as key players. The more MDBs depend on markets, the more likely they are to adjust their activities within a particular compensation logic between autonomy and resources: 'it is not a simple continuum of giving up more or less autonomy in exchange for resources, but rather losing a degree of autonomy to one kind of external authority (bond markets) instead of another (member States)' (Humphrey 2015a: 2).

In this sense, as issuances of MDBs are rated by these agencies according to risk criteria, reducing such risk 'has become a principal justification for conservative financial management in recent decades' (Humphrey 2015b: 15). The resulting tensions began to increasingly mark the political agenda of such agencies: '[m]aintaining IDB's financial strength without falling into such restrictive (financial or operational) criteria will end up limiting IDB's contribution when the region mostly needs it $^{21}$ (Governor for Argentina, IDB Annual Meeting 2003).

This is problematic because, just like with private banks, rating agencies consider that such risk depends largely on the loan portfolio concentration of MDBs (as mentioned above, especially in regional banks such as the IDB or AfDB). It also depends, to a lesser extent, on the PCT given to these banks by borrowing countries (Humphrey 2015b; Perraudin, Powell and Yang 2016). Thus, like rating agencies, investors who buy MDB 
bonds end up interfering (albeit indirectly ${ }^{22}$ ) in the policies of these organisations (Babb 2009; Humphrey 2015b).

Consequently, to exercise their original (development) mandate, MDBs must maintain their debt with a high credit rating that enables low-cost leverage. This led many of these organisations to modify their policies by adopting a more conservative equity-to-loan ratio. Currently, the IBRD can lend up to five dollars for every dollar of its capital, and this ratio has been reduced to free up more lending resources. ${ }^{23}$ In 2017 the IDB switched from calculating its loans based on the callable capital of its non-borrowing members to defining a four-time limit leverage, which complements its current risk-based capital constraint. For its part, the AfDB establishes that its maximum borrowing capacity should not exceed its usable capital, ${ }^{24}$ and this ratio is currently around $80 \%$. This remains at similar levels to those in 2010, after its fall below 50\% in 2013-2014 due to the Bank's sixth capital increase.

Hence, there is a growing concern for the three MDBs analysed to maintain the highest credit score (AAA, in the case of S\&P), even at the risk of becoming more conservative and/or procyclical. However, this path chosen by most MDBs contrasts with the alternative model chosen by the Latin American Development Bank (CAF). CAF's model allowed the Bank to maintain relatively 'worse' ratings (currently A+; S\&P 2019) with greater cash capital (around half of the total; Humphrey 2015b; Ray and Kamal 2019). ${ }^{25}$

\section{Borrowing dynamics}

As mentioned earlier, the literature placed emphasis on analysing capitalisations and, to some extent, leverage, as the main determinants of the resource dependence of MDBs, paying less attention to the size of the loan demand. ${ }^{26}$ Given that the financial model of MDBs also depends on their function as lenders of developing countries (i.e. their 'borrowing function'), these banks must adapt to changes that respond to their clients' preferences.

The effects of the aforementioned borrowing dynamics became more relevant after S\&P's change in methodology (2012). While we previously identified some of the aspects that determine the creditworthiness of MDBs (e.g. PCT), here we want to illustrate the relevance of middle-income countries. More specifically, we analyse the implications on the resource dependence of a portfolio structure under the predominance of a few countries that borrow relatively larger amounts. Of the three banks analysed, the two regional ones (IDB and $\mathrm{AfDB}$ ) have a strong portfolio concentration.

This results from their own mandates (which restrict their clients to the Latin American and African regions, respectively) and from the development levels of their borrowing countries - as the relatively more developed borrowing countries are able to absorb most of the resources offered by these banks. By way of example, the IDB's own mandate assumes 26 countries as its area of influence, of which only five concentrate $80 \%$ of the regional economic activity.

Humphrey and Michaelowa (2013), and Humphrey (2016) find that both the governance arrangements ${ }^{27}$ of MDBs and their clients' macroeconomic strength ${ }^{28}$ have a direct impact on the demand of borrowing countries. The income of these countries is an 
essential resource for the financial sustainability of MDBs. For this reason, such governance arrangements are key to shape the viability of these banks as financial intermediaries through their influence on the demand of borrowers. Completing this approach, but on the agency's side, we state that MDBs are driven by their need to continue lending to the relatively richer (middle-income) countries, not only to meet their demand, but also to protect the quality of their portfolios (Birdsall 2006; Knack, Rogers and Heckelman 2012). Hence, we define this third resource-dependence source as borrowing dynamics and observe that it has recently become more complex. This is due to both the changes in the methodologies applied by risk rating agencies to MDBs and the increasing global economic relevance of their largest borrowers (e.g. China, Brazil, India and Mexico, among others). ${ }^{29}$

And this issue is particularly relevant for the two regional banks studied here. As mentioned earlier, MDBs in general, and RDBs in particular, tend to have a portfolio concentrated on a few countries, given their area of influence and each region's strong heterogeneities. The five main IDB borrowers ${ }^{30}$ account for $69 \%$ of the Bank's sovereign exposure (in 2017, in terms of the active portfolio). ${ }^{31}$ The AfDB's active portfolio is also concentrated: its five largest borrowers ${ }^{32}$ (out of a total of 54 countries) accounted for $55 \%$ of the total (in 2017). For its part, the IBRD's portfolio concentration, albeit lower than that of RDBs given its global nature, is also high, with 10 of its (69) borrowers ${ }^{33}$ accounting for $64 \%$ of its total active portfolio, and with almost $40 \%$ corresponding to its first five clients (on average for 2013-2018).

To contain their portfolio concentration, the three banks applied individual-borrower ceiling policies. Recently, the IDB began to incorporate each country's debt risk, approving in 2015 a limit policy based on a double-level exposure for the sovereign guarantee portfolio. ${ }^{34}$ Meanwhile, the AfDB applies a global exposure limit per country to its sovereign and non-sovereign portfolios that is combined with other capital adequacy determinants. ${ }^{35}$ On its part, the IBRD applies ceilings where a single borrower cannot exceed $10 \%$ of the Bank's total lending capacity, also limiting its large borrowers and with a floor (70\%) to allocate resources to medium-low income countries.

We hence consider that borrowing dynamics become a key player in the resource dependence of MDBs because these banks depend on their largest borrowing countries, which, therefore, forces MDBs to manage different tensions. Among other examples, the IBRD's recently approved capitalisation (April 2018) showed the US reluctant to continue funding an institution with China as one of the main borrowers, or Russia's strong reactions when its operations were suspended.

In addition, the growing role of the market agents, and the aforementioned portfolio concentration penalty in the S\&P's methodology, led these banks to implement different reforms trying to strike the delicate balance of satisfying two important resource dependence sources (leverage and borrowing dynamics). ${ }^{36}$

To sum up, the borrowing dynamics focus on demand (or balance) in the face of changes in borrowing countries and the portfolio concentration of these banks. This, in turn, makes most MDBs (and especially RDBs) not only more concentrated, but also procyclical. We also note that this feature ends up constraining these banks even more 
strongly, since it turns them into market rivals for those middle-income countries to which they need to lend (i.e. those with a good credit rating).

\section{Expanding the scope of borrowing dynamics: two milestones in the recent history of MDBs}

In order to understand the current institutional logic of MDBs, their financial model requires giving greater relevance to changes in resource dependence and, particularly, the borrowing dynamics. To show this, in this last section we explore two recent milestones: the risk exchange agreements between MDBs and the impact of Argentina's selective default (2014-2015) on the IDB's portfolio concentration.

\section{Credit risk exchange agreements (swaps)}

To respond to the aforementioned borrowing dynamics limitations, MDBs signed credit exposure exchange ('swap') agreements (EEAs). EEAs are financial instruments (or risk management tools) that allow MDBs to exchange risk exposures. The initiative was launched in October 2013 by the IBRD and it was supported by the IDB and AfDB, as well as by the G8 and G20 Finance Ministers (see e.g. G20 2015). After two years of development, in November 2015 the Boards of the three mentioned MDBs approved the framework for exchanging their risk exposures. These agreements were signed in order to optimise the balance sheets of MDBs, thus maximising their collective development impact for a given amount of capital contributed by shareholders. ${ }^{37}$

The first three (bilateral) EEA transactions were signed on 15 December 2015 for a combined total of approximately US\$6.5b consisting of sovereign exposures from 37 countries. These three EEAs were envisaged considering that the two RDBs involved (IDB and $\mathrm{AfDB}$ ) operate in different regions, albeit also sharing a common group of shareholder countries (usually non-borrowers). In the agreements signed, the IDB exchanged guarantees from 11 countries $^{38}$ with the IBRD and the AfDB, which included 15 borrowers from their portfolios. ${ }^{39}$ For its part, the AfDB bought the protection of 11 of its borrowing countries $^{40}$ from the IBRD and the IDB, selling it for $13 .{ }^{41}$

The IDB explains that this tool was necessary because ' $\mathrm{i}] \mathrm{n}$ the past, MDBs have managed their capital concentration risks mainly by reducing or limiting exposure in countries where lending volumes were especially high' (The World Bank 2015) (see subsection 'The borrower's importance'). The parties expected these EEAs to have a positive effect on both the capital indices and institutional credit profile of the signatory MDBs.

According to several of the same risk managers who designed them (see Belhaj et al 2016), these swaps represent an important risk-management innovation as they substantially improve the collective financial capacity and development impact of these banks. In other words, these instruments are used to exchange exposures among MDBs in order to reduce their concentration risk, thus rebalancing their portfolios and optimising their 
balance sheets. Such reduction releases part of the existing capital that can be used to improve capital adequacy or to settle additional loans (Belhaj et al 2016).

Humphrey (2017a: 16) defines them as a 'creative piece of financial engineering' to exchange parts of the outstanding loan portfolio of MDBs with each other. Moreover, the head of risk at the IDB (Federico Galizia) explained that these EEAs allow MDBs to insure each other for any potential arrears borrowers may fall into. And, in turn, this reduces the risk of the latter being concentrated on a single institution. It is precisely the portfolio concentration prioritisation of such agencies that makes EEAs necessary.

Indeed, the result of this swap boosted S\&P's capital adequacy assessment, especially for the AfDB and the IDB, enabling an additional loan portfolio space of several billion dollars in each bank. Experts considered that these first three EEAs had the potential to increase financial support to achieve the 2030 Sustainable Development Goals (calculated between US\$15b and US\$20b; Belhaj et al 2016). Shortly after, S\&P (2016b) justified a significant increase in the AfDB's risk-adjusted capital ${ }^{42}$ (RAC, from $18 \%$ in 2014 to $24 \%$ in 2015) due to the reduction in the Bank's single name concentration reached through this swap. This was also the case with the IDB, although to a lesser extent (from 16\% to 19\%), given the bank's exposure in Argentina (see subsection 'The borrower's importance'). But this effect was not sustainable over time: the AfDB's RAC fell again below $20 \%$ 'due to the rapid growth of the AfDB's loan portfolio' (S\&P 2018a: 54).

Therefore, and as the same rating agency shows, these types of instruments, albeit useful in the short-term, are one-time tools and do not seem to solve the capital restriction problem at its root. Along the same lines, Humphrey (2017a) warns that such financial engineering will not have a substantial impact while reforms to callable capital continue facing technical and political obstacles. In fact, he even adds that EEAs could potentially compromise the PCT that countries grant to MDBs, a key aspect of their financial model. This somewhat contradicts the IDB's view (expressed by Federico Galizia) that, since all MDBs benefit from the PCT, and arrears have always been historically resolved without losses, EEAs do not represent an additional risk for these banks (Galizia n.d.).

\section{The borrower's importance: the IDB and Argentina's selective default rating}

A concentrated portfolio also has a direct impact on the borrowing dynamics and the business model of MDBs as a result of changes in some of the main borrowing countries. Some examples in the World Bank include Russia's and China's positions in the latest capitalisation discussions (2018). In this section, we focus on the impact of Argentina's credit rating downgrade to 'selective default' (in 2014) and its relationship to the country's borrowing dynamics with the IDB since 2012.

As mentioned above, a borrower's risk rating refers to the credit score (rating) of such a country's debt (with which the multilateral institution is exposed). If an MDB lends to countries with a low (or poor) credit rating, this deteriorates the bank's financial soundness, which may then result in contradicting its counter-cyclical mandate. 
Even though the case studied is not limited to the IDB or Argentina, ${ }^{43}$ this case makes it possible to analyse how such borrowing dynamics constitute a relevant aspect of resource dependence. As noted earlier, the IDB's five main borrowers account for $69 \%$ of the Bank's exposure, and Argentina alone accounts for about 18\%. Over the 2012-2014 period, the country's credit rating (CCC-) was among the worst in the region. In the context of the so-called 'vulture funds' conflict, Argentina was downgraded (in July 2014) to SD as a result of the payment chain interruption imposed by an US court ruling in favour of these funds ${ }^{44}$ (see López and Nahón 2017 for further details).

Portfolio concentration and a borrower's risk rating mutually reinforce each other (i.e. the latter is enhanced with the former's high levels). Also, given the IDB's high level of exposure to Argentina, the downgrade of the country's rating impacted directly on the Bank's portfolio rating. Thus, in 2014, the IDB's portfolio rating fell from BBB for $95 \%$ to $80 \%$ of the total (with around $18 \%$ in SD). This exposure to Argentina, especially due to S\&P's methodological (i.e. risk-weighted) changes in 2012, had an important impact on the Bank's available capital. Following S\&P's model, the IDB's credit profile worsened. ${ }^{45}$

Bearing in mind that the financial and risk management model of each bank determines their interest rate levels and lending capacity, based on their aggregate risk level, among other variables, the aforementioned context stressed the IDB's options to maintain a level of capital adequacy that would allow it not to lose its AAA rating. In order to compensate for the greater risk, such alternatives included: increasing capital, lending less to the country in question, and/or charging higher rates. Below we analyse the dynamics of each of these three options.

As mentioned above, capital increases are an area of political dispute. The IDB has a shareholder with veto power (the USA, which contributes one third of the Bank's capital ${ }^{46}$ ) that restricted this option (e.g. viable in CAF). The Bank could then increase the financial costs of its loans (to the detriment of the other borrowers) or cut its loan approvals for Argentina (and/or increase approvals for countries with better credit scores) to decrease its portfolio concentration with that country. The limits of the latter option are clear: due to its mandate, the Bank has a limited number of clients, and the possibility of redirecting loans among them (especially in the short-term) is subject to each country's absorption capacity.

In such a scenario, the IDB chose to significantly cut its operations with Argentina - a clearly conservative and restrictive measure of its original development mandate for the country. As Humphrey illustrates:

When a borrower country with a substantial portfolio of outstanding loans faces a sudden shock, an MDB has an incentive to reduce or cut off lending to that country, for fear of negatively impacting its own credit rating and/or using excessive amounts of equity capital (Humphrey 2015b: 10).

Thus, while the average annual sovereign approvals with Argentina over the previous 15 years had exceeded the US\$1.3b annual average (14\% of all approved loans), in 
2013-2015 such measure dropped to US\$970m (7.4\% of total approvals), and just over US $\$ 800 \mathrm{~m}$ annually in 2014 and 2015. In this regard, the IDB clearly affected its counter-cyclical (or, at least, acyclical) mandate with respect to one of its main borrowing countries.

\section{Conclusions}

One of the main foundational strengths of MDBs - which partly synthesises the New Deal spirit, but on a global scale - was their cooperative nature based on the capital contributions from non-borrowing developed countries. This, in turn, has allowed these banks to guarantee more favourable financial conditions for their borrowers. Considering this 'basic or simplified model' of their resource dependence, the literature has generally concentrated on studying how developed countries impose conditions and shape the dynamics of these institutions. In this paper, and following more recent and innovative contributions, we have analysed the resource dependence dynamics of MDBs considering three funding sources: capital contributions, bond market issuing leverage, and borrowing dynamics (synthesised in Figure 2). Finally, we also analysed two recent milestones that allow us to establish the relationships among these three sources.

Figure 2 - How the current resource dependence of MDBs weakens their development mandate

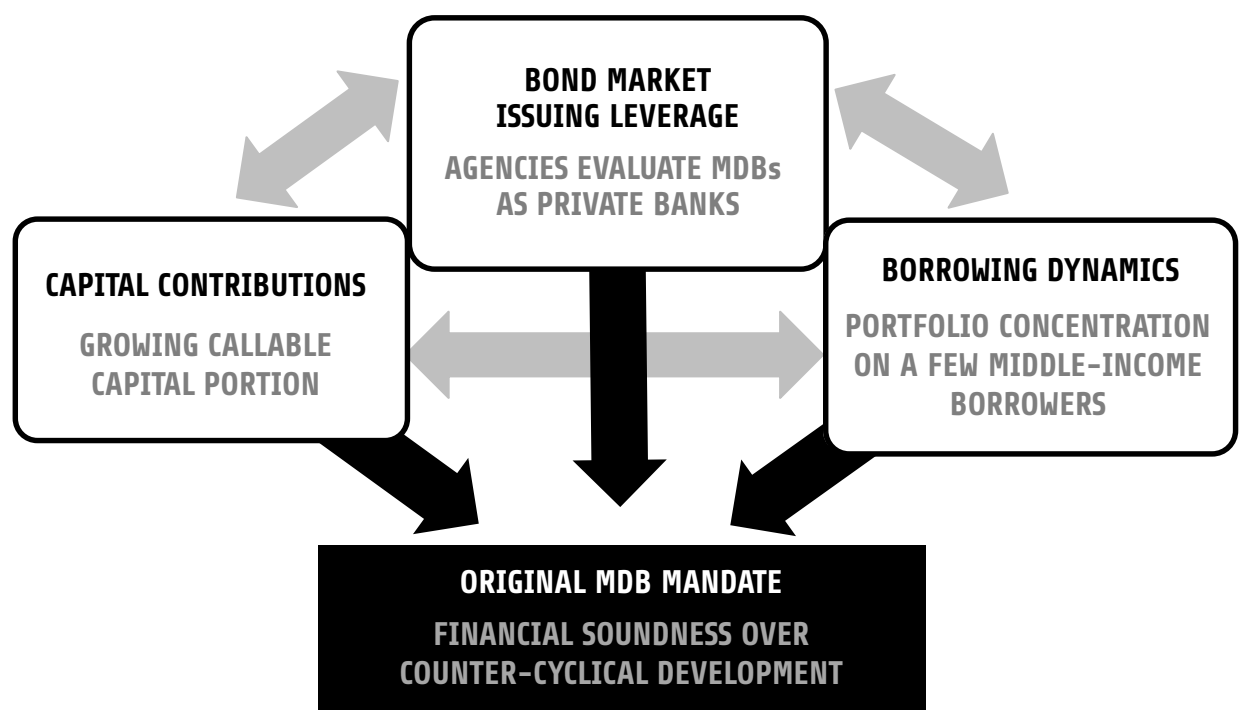

Source: Created by the authors.

First, even though capitalisations remain central to expand the activities of these banks and, in fact, they have doubled in volume, these contributions do not indicate a resource disbursement. This is due to the low (and falling) share of cash, where most capital is 
callable. In the current composition of the MDBs analysed in this paper (IBRD, IDB and AfDB), the paid-in capital share ranges between $3.5 \%$ and $8 \%$. Capital contributions then constitute a support signal from shareholder countries. This is because one of the main assets to obtain resources in the private market - leveraging - relies on the callable capital of banks, in a volume that is equivalent to the annual disbursements of the three aforementioned MDBs. As noted earlier, the financial soundness of MDBs is hence both material and symbolic, as markets depend on sovereign States' signals regarding the safety of buying their issued bonds.

Such signals are mainly codified by credit rating agencies which, with an analysis that is not precisely sensitive to the special features of these non-commercial banks, end up exerting a significant influence on some of the most relevant concerns of MDBs (e.g. portfolio concentration, PCT, and required capital strength). The analysed risk swap was intended to meet these requirements through an accounting move. Recent and more conservative responses in the same lines were modifications in capital adequacy policies of these MDBs. As mentioned above, in the three banks analysed, the first decile of borrowers (between five and 10 countries, all of them, middle-income) absorbs over 55\% of their resources, showing a clear portfolio concentration that sought to be financially attenuated with swaps. However, this portfolio concentration has also made MDBs more vulnerable to the preferences of a small group of countries.

And this third source of funding resources (which we call borrowing dynamics) is not only linked to a matter of preferences and financing attractiveness especially for middle-income countries, but, due to portfolio concentration, it also exposes MDBs to temporary changes in the general conditions of their borrowing countries. The analysis of the Argentine case in its dynamics with the IDB (during 2014-2015) shows that an exogenous change triggered tension between prioritising market - over borrower-dependence. Instead of increasing the financial costs of loans, the IDB chose to cut its approvals for the country (and, in some cases, increased them for other countries with better ratings and with absorption capacity and interest) to reduce its exposure with Argentina. Hence, the (2012) change in the approach of S\&P, together with the specific situation of some borrowing countries, added further tension to the logic of resource dependence.

And this brings us to the third (and last) consideration that we would like to highlight in these conclusions: the interdependence among the three funding sources. There is tension among demanding greater efforts from contributing countries, relying on the market or heeding the preferences of large borrowing countries (in terms of costs, types of transactions, etc.). The three banks analysed have tended to prioritise market funding sources, driven by the preferences of non-borrowing countries that do not need to make great capitalisation efforts. And this has, in turn, significantly weakened the counter-cyclical development mandate of MDBs.

We envisage two lines for future research. On the one hand, it would be interesting to expand the analysis to other cases, especially those banks where all countries are borrowing members, e.g. the CAF or the Islamic Development Bank. On the other hand, a second line would involve studying the extent to which the new MDBs created in the $21^{\text {st }}$ 

cooperative principle focus.

\section{Notes}

1 Translated into English by the authors.

2 Such inspiration can be seen in two dimensions. First, in the institutional design of these regional banks, where it is possible to observe a lot of similarities, especially with the World Bank. In addition, they were inspired to generate development financing options, expressing, as Tussie (1997) states for the IDB, the dissatisfaction of some Latin American countries with the World Bank's lack of attention to the region.

3 Among the widespread differences between both types of banks, Humphrey (2017b: 9) identifies: callable capital, loan concentration, preferred credit treatment, mission, ownership and balance sheet, and lack of regulator and lender of last resort. This paper emphasises the first three and discusses the remaining throughout the analysis.

4 'Since 2011, the USA [...] started to oppose the approval of loans for Argentina [as] a reprisal measure [...] for contractual breaches following Argentine 1998/2002 crisis [...] The US position has had the support of other developed countries and Spain has joined them after the nationalisation of the $51 \%$ share that Repsol had in YPF until 2012 [...] in the World Bank [...] the 2013/2015 strategic alliance, which was going to result in disbursements of a billion dollars annually, was supposed to be voted [in 2012], and that decision was delayed'. (translated into English by the authors; Rebosio 2013).

$5 \quad$ YPF had been privatised in 1992 and subsequently (in 1999) acquired by a Spanish company (Repsol). In May 2012 the Argentine Congress approved a project to expropriate 51\% of YPF's shares.

6 'The US Government [...] warns that it is a measure that can have "negative effects" for Argentina's economy', urging 'Argentina to normalise its relations with the international financial community' (Caño 2012).

7 Translated into English by the authors (Clarín 2012). See also: Rebosio (2012a, 2012b). Also, the then President of The World Bank Group (Robert Zoellick) called 'Argentina's move to seize control of the country's biggest energy company from Spain's Repsol 'a mistake', joining a chorus of international criticism' (Wroughton 2012).

8 While S\&P (2018b) adjusted some of these issues in the agency's last review, they are still valid to address the cases analysed in the section 'Expanding the scope of borrowing dynamics', when the 2012 methodology was in effect. This highlights the relevance of this stakeholder in the institutional dynamics of MDBs.

9 Further, Gordy and Lütkebohmert (2013) add that those banks with small portfolios could suffer a 3\% to $20 \%$ capital adjustment due to the concentration penalty (Humphrey 2015b).

10 Perraudin, Powell and Yang (2016) illustrate that PCT was not even questioned by Argentina in its 2002 default, as the country, despite the serious economic crisis it faced, kept up to date on every IDB and IMF payment. And this also happened in 2015 with the ruling in favour of one of the holdouts within the (2005/2010) Argentine debt restructuring (in the so-called 'vulture funds crisis'; see López and Nahón 2017).

11 Currently France holds a voting power of $3.8 \%$ at the AfDB.

12 Humphrey shows the 'conceptual confusion on S\&P's part on how to cope with callable capital within their quantitative RAC framework' (Humphrey 2017b: 18). Instead of adjusting the required AAA capital to the final MDB score (like S\&P), he adds it to the equity.

13 Even though financial strength is a constant evaluation criterion in these banks, the requirement to maintain a triple A rating in the IDB was explicitly incorporated within the framework of the Bank's last capitalisation (GCI-9, in 2010).

14 Park and Strand (2016) add special funds, generally contributed by a single member or designed to move towards a particular policy area. We do not analyse them in this article because they depend on the contributor's interest and do not exert any leverage on the market.

15 Replenishments are specific of the concessional windows for the poorest countries and are voluntarily and periodically renewed (every 3-5 years). 
16 The Latin American Development Bank (Corporación Andina de Fomento, CAF) is one of the exceptions (Ray and Kamal 2019).

17 Since the delegation of countries to MDBs is a non-linear relationship, as suggested by Lyne, Nielson and Tierney (2006), this entails dynamics of collective principals. These authors argue that large shareholders would not dominate MDBs since they need the cooperation of smaller members. This poses a dilemma for the former (generally developed) countries in terms of the extent to which they are able to support and influence MDBs without fully dominating them. However, we observe that this does not predominate in the processes of capitalization of the MDBs, since the veto powers are usually exercised for this type of strategic decisions.

18 Translated into English by the authors.

19 Both the PCT of borrowers' debt commitments and the almost non-existent history of default constitute pillars of such trust.

20 In practice, this level is even more conservative, e.g. amounting to $62 \%$ (as of June 2018).

21 Translated into English by the authors.

22 For example, investors may withhold from buying bonds of MDBs and hence downgrade their credit ratings.

23 This Bank's equity-to-loan ratio fell from $25.7 \%$ in 2014 to $22.9 \%$ in 2018.

24 Such usable capital is the amount of callable capital of members with a rating of, at least, AA plus reserves and paid-in capital.

25 This relatively high paid-in capital also results in lower leverage rates and allows CAF to maintain its bond ratings below AAA.

26 Park and Strand (2016) and Humphrey (2015a) point out the lack of attention in the literature to the credit exposure of banks with borrowing countries. Some studies explicitly consider the role of demand (e.g. Ratha 2005; Knack, Rogers and Heckelman 2012), but explain the access of countries to loans from MDBs and look at their impact on the institutional dynamics and governance of banks.

27 The non-financial characteristics of the IBRD, IDB and AfDB vary as a direct function of the power balance between borrowing and non-borrowing shareholders, and are important determinants of the loan demand from the former.

28 'The rapid rise of numerous middle-income countries in recent years [...] and the explosive growth of international capital flows may mean this model needs rethinking to face a new set of financial pressures: declining demand from borrowers' (Humphrey 2015a: 18).

29 These countries have recently had greater fiscal soundness and more options for their sovereign financing.

30 The five largest IDB borrowers are Brazil, Argentina, Mexico, Colombia and Ecuador.

31 Active portfolio is defined by loans in disbursement and repayments.

32 The AfDB's five largest borrowers are Morocco, Tunisia, Egypt, South Africa and Nigeria.

33 The IBRD's ten largest borrowers are Brazil, Indonesia, Mexico, China, India, Turkey, Colombia, Egypt, Poland and Argentina.

34 The IDB's GCI-9 also established a minimum of $35 \%$ of total loans to be lent to small and vulnerable countries in the region.

35 The total exposure to any borrower must not exceed $15 \%$ of venture capital.

36 Other factors which are beyond a borrower's control have an impact on the business model of MDBs, as shown by the case in which Argentina faced the vulture funds crisis (see López and Nahón 2017).

37 Prior to their implementation, MDBs managed their concentration risk by reducing their loans to countries with which they had high exposure (see section 'The borrower's importance') or with capital increases.

38 These 11 countries were: Ecuador, Brazil, Mexico, Argentina, Dominican Republic, Colombia, Panama, Trinidad and Tobago, Bolivia, Chile and Costa Rica (IDB 2018).

39 These 15 countries were: Morocco, Tunisia, Egypt, Indonesia, Turkey, Pakistan, Serbia, Jordan, Macedonia, Armenia, Montenegro, Bosnia and Herzegovina, Georgia, Nigeria and Angola (IDB 2018). 
40 These 11 countries were: Angola, Botswana, Gabon, Namibia, Nigeria, and South Africa (IBRD), and Angola, Egypt, Morocco, Nigeria and Tunisia (AfDB, Financial Statements 2018).

41 These 13 countries were: Albania, China, India, Indonesia, Jordan, Pakistan, Romania and Turkey (IBRD), and Argentina, Brazil, Ecuador, Mexico and Panama (AfDB 2018).

42 The risk-adjusted capital is S\&P's main indicator to measure capital adequacy, considering the risk of borrowing countries.

43 For example, when reviewing (in October 2014) CAF's downward rating trend, S\&P mentions that 'there is a greater probability among three that the continued deterioration of Venezuela's macroeconomic fundamentals weakens the risk-weighted capital adequacy, while Argentina is still in default on its discount bonds' (S\&P 2014).

44 In fact, Argentina made the required payments. Judge Thomas P. Griesa's sentence prevented them, making it (both politically and economically) unfeasible for the country to pay the holdouts, at least up until the end of 2014 (Guzmán 2016).

45 The IDB's RAC went from 17\% (in 2013) to 16\% (2014) and 19\% in 2015 (S\&P 2016b). Unlike its analysis for the AfDB, in the case of the IDB, S\&P does not mention the effect of the EEAs on the IDB's RAC. This measure exceeded $20 \%$ after 2016, when the Argentine rating began to improve following its payment to the vulture funds.

46 That said, as mentioned, S\&P's formula (2012) does not take such capital into account.

\section{References}

African Development Bank (AfDB). 2018. 'Financial Report 2018.' At https://www.afdb.org/en/documents/financial-report-2018 [Accessed on 23 July 2020].

Babb, S. 2009. Behind the Development Banks: Washington Politics, World Poverty, and the Wealth of Nations. Chicago: University of Chicago Press.

Belchior, M. 2013 'Speech delivered at 54th IDB Annual Meeting.' Panama, 14-17 March.

Belhaj, R, M Baroudi, N Fiess, J C de Olivera, F Sperling and T Turner. 2016. 'Exposure exchange agreements among multilateral development banks for sovereign exposures: An innovative risk management tool.' Journal of Risk Management in Financial Institutions 10 (1): 78-88.

Berglof, E. 2015. 'The Bretton Woods institutions reinventing themselves.' In M Uzan (ed), Bretton Woods: the next 70 years. Reinventing Bretton Woods Committee. New York: Prudential Investment Management, pp. 33-37.

Birdsall, N. 2006. 'The Hardest Job in the World: Five Crucial Tasks for the New President of the World Bank.' In N Birdsall (ed), Rescuing the World Bank: a CGD Working Group Report and Selected Essays. Washington, DC: Center for Global Development, pp. 13-65.

Boz, E. 2011. 'Sovereign default, private sector creditors, and the IFIs.' Journal of International Economics 83 (1): 70-82.

Caño, A. 2012. 'EE UU advierte a Argentina de los "efectos negativos" de expropiar YPF.' El País [online], 18 April. At https://elpais.com/economia/2012/04/18/actualidad/1334774306_560718. html [Accessed on 23 July 2020].

Clarín [online]. 2012. 'En represalia por YPF, España traba créditos del BID al país.' 8 June. At https://www.clarin.com/economia/represalia-ypf-espana-creditos-bid_0_HJN04QhPme.html [Accessed on 23 July 2020].

Galizia, F. n.d. 'Exposure Exchange Agreements (EEA) Among MDBs.' At https://www.cefpro.com/ wp-content/uploads/2016/05/11.10-FedericoGalizia.pdf [Accessed on 23 July 2020]. 
George, S. 2004. Otro mundo es posible si... Barcelona: Icaria Editorial.

Gordy, M B and E Lütkebohmert. 2007. 'Granularity Adjustment for Basel II.' Discussion Paper Series 2: Banking and Financial Studies 01/2007. Frankfurt: Deutsche Bundesbank.

2013. 'Granularity Adjustment for Regulatory Capital Assessment.' International Journal of Central Banking 9 (3): 33-71.

Graham, E R. 2017. 'Follow the Money: How Trends in Financing Are Changing. Governance at International Organizations.' Global Policy 8: 15-25.

Group of Twenty (G20). 2015. Multilateral development banks action plan to optimize balance sheets. Antalya: G20.

Guzmán, M. 2016. 'An Analysis of Argentina’s 2001 Default Resolution.' Centre for International Governance Innovation Paper No. 110.

Helleiner, E. 2015. 'International Policy Coordination for Development: The Forgotten Legacy of Bretton Woods.' Discussion Paper No. 221. New York and Geneva: United Nations Conference on Trade and Development (UNCTAD).

Helleiner, E and H Wang. 2018. 'Limits to the BRICS' challenge: credit rating reform and institutional innovation in global finance.' Review of International Political Economy 25(5): 573-595.

Hirschman, A O. 1970. Exit, voice, and loyalty: Responses to decline in firms, organizations, and states. Cambridge and London: Harvard University Press.

Humphrey, C. 2015a. 'The Invisible Hand: Financial Pressures and Organisational Convergence in Multilateral Development Banks.' The Journal of Development Studies 52 (1): 92-112.

2015b. 'Are credit rating agencies limiting the operational capacity of multilateral development banks?' Paper commissioned by the G-24 as part of its work program on enhancing the role of $M D B s$ in infrastructure finance. New York and Geneva: UNCTAD.

2016. 'The "hassle factor" of MDB lending and borrower demand in Latin America.' In S Park and J R Strand (eds), Global Economic Governance and the Development Practices of the Multilateral Development Banks. London and New York: Routledge, pp. 167-190.

2017a. 'Six proposals to strengthen the finances of multilateral development banks.' Working Paper 509. London: Overseas Development Institute.

2017b. 'He who pays the piper calls the tune: Credit rating agencies and multilateral development banks.' The Review of International Organizations 12 (2): 281-306.

Humphrey, C and K Michaelowa. 2013. 'Shopping for development: Multilateral lending, shareholder composition and borrower preferences.' World Development 44: 142-155.

Inter-American Development Bank (IDB). 2018. 'Informe Anual 2017. Estados financieros.' At https://publications.iadb.org/bitstream/handle/11319/8825/Banco-Interamericano-de-Desarrolloinforme-anual-2017-Estados-financieros.pdf?sequence=3\&isAllowed $=y$ [Accessed on 23 July 2020].

Knack, S, F H Rogers and J Heckelman. 2012. 'Crossing the threshold: A positive analysis of IBRD graduation policy.' Review of International Organizations 7: 145-176.

Lavelle, K C. 2011. Legislating International Organization: The US Congress, the IMF and the World Bank. Oxford: Oxford University Press.

López, P J and C Nahón. 2017. The Growth of Debt and the Debt of Growth: Lessons from the Case of Argentina. Journal of Law and Society 44 (1): 99-122. 
Lyne, M, D Nielson and M Tierney. 2006. 'Who delegates? Alternative models of principals in development aid.' In D Hawkins, D Lake, D Nielson and M Tierney (eds), Delegation and Agency in International Organizations. Cambridge: Cambridge University Press, pp. 41-76.

Mayeda, A and J Shankleman. 2018. 'World Bank Edges Near Capital Boost as U.S. Drops Objection.' Bloomberg [online], 21 April. At https:/www.bloomberg.com/news/articles/2018-04-21/worldbank-moves-closer-to-capital-boost-as-u-s-drops-objection [Accessed on 23 July 2020].

Moody's. 2013. Multilateral Development Banks and Other Supranational Entities. London.

Nemiña, P and J Larralde. 2018. 'Etapas históricas de la relación entre el Fondo Monetario Internacional y América Latina (1944-2015)'. América Latina en la historia económica 25: 275-313.

Oficina de Evaluación y Supervisión (OVE). 2018. Noveno Aumento General de Capital del BID: Implementación y Resultados. Washington, DC: Banco Interamericano de Desarrollo.

Park, S and J R Strand. 2016. 'Global Economic Governance and the Development Practices of the Multilateral Development Banks.' In S Park and J R Strand (eds), Global Economic Governance and the Development Practices of the Multilateral Development Banks. London and New York: Routledge, pp. 3-20.

Perraudin, W R M, A Powell and P Yang. 2016. 'Multilateral Development Bank Ratings and Preferred Creditor Status.' IDB WORKING PAPER SERIES No IDB-WP-697.

Rapoport, M and F Médici. 2007. 'Corazones de izquierda, bolsillos de derecha: el New Deal, el origen del FMI y el fin de la gran alianza en la posguerra.' Desarrollo Económico 184: 505-537.

Ratha, D. 2005. 'Demand for World Bank lending.' Economic Systems 29: 408-421.

Ray, R and R Kamal. 2019. 'Can South-South Cooperation Compete? The Development Bank of Latin America and the Islamic Development Bank. Development and Change 50 (1): 191-220.

Rebosio, A. 2012a. 'España deberá sumar aliados si quiere bloquear créditos a Argentina.' El País [online], 25 April. At https://elpais.com/economia/2012/04/25/actualidad/1335387207_404037. html_[Accessed on 23 July 2020].

2012b. 'Los aliados que debería sumar España para bloquear créditos a Argentina.' El País, Blogs Planeta Futuro [online], 27 April. At https://blogs.elpais.com/eco-americano/2012/04/los-aliados-que-deber\%C3\%ADa-sumar-espa\%C3\%B1a-para-bloquear-cr\%C3\%A9ditos-a-argentina. html [Accessed on 23 July 2020].

. 2013. 'El Banco Mundial volverá a prestarle a Argentina.' El País [online], 11 October. At https://elpais.com/internacional/2013/10/11/actualidad/1381506332_109789.html [Accessed on 23 July 2020].

Standard and Poor's (S\&P). 2012. Metodología para calificar instituciones multilaterales de financiamiento y otras instituciones supranacionales. New York.

2014. 'Standard \& Poor's revisa perspectiva a negativa de Corporación Andina de Fomento; confirma calificaciones de "AA-" y "A-1+."

2015. Supranationals Special Edition 2015. New York.

.2016a. RatingsDirect. Inter-American Development Bank. New York.

. 2016b. Supranationals Special Edition 2016. New York.

2018a. Supranationals Special Edition 2018. New York.

2018b. Metodología para calificar instituciones multilaterales de financiamiento y otras insti-

tuciones supranacionales. New York. 
Strand, J R and M W Trevathan. 2016. 'Implications of accommodating rising powers for the regional development banks.' In S Park and J R Strand (eds), Global Economic Governance and the Development Practices of the Multilateral Development Banks. London and New York: Routledge, pp. 121-142.

The World Bank [online]. 2015. 'Development Banks Working Together to Optimize Balance Sheets.' Press release, 22 December. At https://www.worldbank.org/en/news/press-release/2015/12/22/development-banks-optimize-balance-sheets [Accessed on 23 July 2020].

2018. President Speech, 19 April. At http://www.worldbank.org/en/news/speech/2018/04/19/ world-bank-group-president-jim-yong-kim-opening-remarks-at-the-2018-spring-meetings-opening-press-conference [Accessed on 23 July 2020].

Tussie, D. 1997. El Banco Interamericano de Desarrollo. Buenos Aires: FLACSO.

Weiss, T G and R Wilkinson. 2013. International organization and global governance. London and New York: Routledge.

Wroughton, L. 2012. 'World Bank says Argentine move on YPF "a mistake.” Reuters [online], 19 April. At https://www.reuters.com/article/uk-worldbank-repsol/world-bank-says-argentine-moveon-ypf-a-mistake-idUKBRE83I0VL20120420 [Accessed on 23 July 2020].

Vivares, E. 2013. El Banco Interamericano de Desarrollo en la década neoliberal. Quito: FLACSO.

\section{About the authors}

Andrea Molinari is a Researcher at CONICET/IIEP-BAIRES, Professor in the Faculty of Economic Sciences at the University of Buenos Aires, and Doctor in Economics (University of Sussex). Her main field of study is international economics, with a focus on regional productive integration, South-South cooperation and financing for development. Andrea has extensive professional and academic experience. She has worked both in national and international institutions (Inter-American Development Bank, African Development Bank, Ministry of Industry of Argentina, European Commission, the World Bank and Central Bank of Argentina). In academia, she has taught international economics, European economy, macroeconomics and microeconomics (in Argentina and the United Kingdom). She wrote several international political economy articles, mainly analysing multilateral and regional development banks, and has become an expert in the field.

Leticia Patrucchi is a Sociologist (University of Buenos Aires) with a Master's degree in Public Administration (University of Buenos Aires). Currently, she works as a Teaching Researcher at the National University of Moreno and the National University of General Sarmiento. Her main field of study is development and State capacity, and she has written various national and international political economy articles. Also, she has developed her

professional activity at the municipal and national levels of Government in international relations topics. She worked as Coordinator of Institutional Relations with International Credit Organizations of the (then) Ministry of Economy and Public Finance of Argentina (between 2011-2015). 


\section{Bancos Multilaterais de Desenvolvimento: Mandato Contra-cíclico e Restrições Financeiras}

Resumo: Dada sua atratividade como fonte de financiamento para os países menos desenvolvidos, os bancos multilaterais de desenvolvimento (BMDs) cresceram em quantidade e tamanho apoiados por suas fontes peculiares de financiamento. Acreditamos que essa 'dependência de recursos' não tenha sido suficientemente questionada na literatura dos BMDs, especialmente no que diz respeito à exposição de crédito que essas organizações têm com seus maiores membros tomadores de empréstimos. Este trabalho caracteriza e identifica os efeitos diferenciais das três fontes que compõem a dependência de recursos nos BMDs: aportes de capital, alavancagem nos mercados e sua função de crédito. Analisamos essas fontes particularmente no Banco Internacional para Reconstrução e Desenvolvimento (BIRD), no Banco Interamericano de Desenvolvimento (BID) e no Banco Africano de Desenvolvimento (BAD) e em dois eventos recentes: a troca de riscos implementada pelos referidos BMDs em 2015 e o efeito da inadimplência seletiva da Argentina na adequação de capital do BID (2014). Encontramos uma crescente relevância da alavancagem e do tamanho dos empréstimos, que modela a dependência de recursos que enfraquece o mandato de desenvolvimento dessas organizações.

Palavras-chave: bancos multilaterais de desenvolvimento; dependência de recursos; condicionalidades; risco de mercado; mandato de desenvolvimento.

Received on 15 September 2019, and approved for publication on 3 March 2020.

\section{(c) BY-NC} https://creativecommons.org/licenses/by-nc/4.0/ 